\title{
On the Integration of Confucian Culture and College Students' Management
}

\author{
Jian-Ming LIU \\ School of Business Administration, Zhongnan University of Economics and Law, Wuhan, China \\ Liujianming@zuel.edu.cn
}

Key words: Confucian culture; college student management; integration

\begin{abstract}
College Student Management is an important part of higher education management. The traditional Confucian culture, which has been handed down for more than five thousand years, still has the value of reference for the management of contemporary colleges and universities. This article applies the management theory of Confucian "people-oriented" "benevolence", "harmony but different", "self-cultivate to appease others" and "harmony is most precious" to the contemporary college students' management practice, and explores the implementation path of the work of College Students under the new situation.
\end{abstract}

\section{Introduction:}

The development of contemporary college students is gradually showing the characteristics of creativeness, personalization and independence. Students' enthusiasm for learning and student work is enhancing, and their ability to restrain themselves is increasing, that is distinct different from the traditional college students. By taking students as the main body, the emphasis of College Students Work is treating every student equally and respecting each student's personal practice, and to create educational opportunities for every student for stimulate their potency, fully tap their value, develop their personality, and ultimately achieve a comprehensive the development of each student. The core idea of Contemporary Student Work is consistent with Confucianism. Based on the actual situation of Chinese college students' work, this article tries to explore the new path of the evolution of college student management by combining the Confucian management thought with the practical work of College students.

\section{People-Oriented---Taking Students As the Main Body}

Confucian culture is taking "people" as the core and "people-oriented" is the core of the Confucian management thought. In the Confucian view, people are the country's base of politics; only people love of polity can realize the view of whom the Popular One Wins the World and of the state serves its people. Also, only a view of students-based in the job of modern university students, that to respect and care for students, to meet the reasonable needs of the people and the interests of the premise, and give full play to students' creativity as the work of college students, can be able to continue to enhance the cohesion and competitiveness and creativity of universities.

The main objectives and tasks of university is to cultivate outstanding talents who adapt to the social development needs, all the daily work in Colleges and universities should be carried out around the central task of moral education. Contemporary college students' work is an important part of the management of colleges and universities, is the ideological and political education. In the new situation, college student management should highlights the main body of respecting students, pay attention to the view of "transposition consideration", respect students' innovative ideas by creating a more free campus environment and management mode, and gradually develop college students' ideological consciousness and self-discipline, turn the external educational management into internalized self-discipline and self-management of students thinking patterns.

Colleges and universities should be from their own reality in the work of the students, in order to effectively carry out the "student centered" philosophy guiding service concept, construct the student work system of humanity and personification. College student workers should also turn from the 
traditional "master", "nanny" into "learning mentor" and "life friends" of college students. Gradually improve the college students' ability evaluation system, and integrate the school education resources for the development of students' comprehensive service. Only in this way can we create a sense of identity and belonging, and truly become the masters of colleges and universities, so as to promote the innovation of college student work system.

\section{Benevolence-- A Foundation of Caring for Students}

Mencius once said, benevolent people are full of affection, others respect them. The one who loves others, others will always love him; respect others, others will respect him. (Li Lou) In Confucianism, "benevolence" should be full of kind and merciful, should possesses quality of respect, love, kindness, loyalty and forgiveness. Fundamental of management activities is "Benevolence". All men are equal in the eyes of the "benevolent", they should be given equal status without distinction. Similarly, the regulators and the regulated should love each other. Confucianism holds the idea that managers should be full of "benevolence", the regulators and the regulated should be "benevolent" treat each other. Contemporary college students have a strong sense of self, passion, desire for independence and equality of personality, they want to be treated equally, and hope that the value of self can be affirmed and respected. The author believes that the college student workers should take students as "active participant" and "responsible" in daily student management work, and give full play to the initiative of students, so that to realize a perfect unity of "self-management" and "management participation".

"Self-management" refers to a process of enhancing students' quality and ability by turning to be responsible for their own learning and life from the subjective consciousness under the guidance of society and the school. Materialist dialectics points out that in the factors of "change", the external cause is the condition, the internal cause is the basis, and the internal cause is the basis of the external cause. Indeed, the college administrators are an important group of students work, shall be managed, but students from various aspects, we should be aware that should be the management of the school management is inducible, should actively inspire, guide students to give full play to the initiative, to achieve "self-management". The "student oriented" concept of College Students' work must follow the democracy, let students participate in the management of colleges and universities, is conducive to the development of colleges and universities, can be more close to the "student oriented" concept. Of course, in order to realize the students' "self-management" and "participation in management", it is necessary for colleges and universities to pay attention to improving the overall strength of the students' organization and cultivating the management ability of the students.

\section{Harmony but Different--- A Measure of Cultivating Personality}

The Confucian view of "harmony but different, the villain is same but not Peaceful", Confucius theory "Harmony" is the highest value of Confucian management goals. The "Harmony" is not the same or a mechanical consistent, but is decided through independent thoughts and choices, to achieve the perfect unity in the process of a combination of "the difference, confrontation and competition" and a high level of management with a kind of consistent "moral pursuit" "harmony". But "the same" means no different factors, different voices or different opinions, just simple addition by the same thing, thus do not produce a new state or new things. Therefore, "harmony" is not a simple one, but a unity of difference. "Harmony but different" is the fundamental principle and rational objective to correctly handle the relationship of people.

Combined with the specific work of university and college students, the author believes that each student's individual differences should be recognized and respected during the university and college student work. Teach any level regardless means people are originally different with wise and foolish or filial and unfilial, but through education these differences can be just eliminated. This is called "teach with no class distinction", referred to as the "education for all". The so-called "Teaching Students in Accordance with Their Aptitude", that is to say, there is a difference among people due to human nature. It is not good to "across the board" towards different characteristics of 
college students, but to cultivate students by adopting different methods and standards, to develop suitable management method for different personality characteristics of students, to motivate their subjective initiative, so as to promote the comprehensive development of personalized and comprehensive quality. Only students of different personalities are concerned and developed, can play students the main advantages and then promote the progress and development of higher education so that colleges and universities can continue to transport every kind of excellent talents for the society.

\section{Self-cultivate to Appease Others--- "Self-Cultivation" is a Key}

The Doctrine of the Mean says in the chapter: "the mandate of heaven ishuman nature, acting according to nature is Dao, cultivating Dao is educat ion." "Self-cultivate to appease others" is proposed for managers' quality requirements, in a nutshell, "words and deeds" is required by the managers. They must first "self-cultivation", then second to "cultivate to appease others", in the mind to put themselves in the middle group, to handle the relationship between individuals and groups, to equally treat themselves and the regulated, whenever and wherever possible to think of others. "A man of integrity will do without instructing, while the one without it idles around with mean instructions." Only to establish a good relationship of trust between the regulators and the regulated, can management activities be effectively implemented and maintained. As teachers, college student workers are the model for students, they should improve their comprehensive quality, and guide students to establish a correct outlook of world, life and values as an exemplary role. Colleges and universities should standardize the requirements of counselors and form a sound screening, evaluation and evaluation system. They should focus on the training and evaluation of quality includes morality, knowledge and ability. Specific requirements are as follows: Ideological and political quality.

As students' life mentors, full-time counselors in universities should be a good role model, subtly impart good moral characters to students; Knowledge quality. Full-time counselors in university should have a perfect speculative knowledge foundation and accomplishment of political theory. They have a good grasp and use of the fundamental of the Marxism, Mao Zedong thought and Deng Xiaoping theory from theoretical and practical aspects, such as sociology, management, ethics, psychology, information science and other disciplines of knowledge, through which to find the common topics with students in daily life, so as to have a deeper understanding and grasp of the students' ideology, mode of thinking, and ultimately achieve effective management; Ability quality. Full-time counselors in university should have strong organizational management, communication and coordination, and language skills. A student work manager usually need to organize students to carry out collective league activities and class activities, and need to coordinate and communicate inside and outside the school, among the different departments of the College, therefore, abilities of "coordination", "interpersonal communication" are essential. Full time counselors also need a certain degree of innovation, develop in the constant practice of student work, at the same time, full-time counselors should actively guide students to break the tradition, and develop their creative ideas.

\section{Harmony Is Most Precious---Aim at "Interpersonal Harmony"}

Doctrine of the Mean said: "The mean is the fundamental of everything under heaven, and harmony is the universal law. With the mean and harmony, the earth moves orderly, and everything their own grows and flourishes." The Analects also said that: "The function of the ceremony is to make the harmonious relationship between people as valuable. The former King managed state affairs like this; but it won't work when simply to accord for harmony without etiquette control." Confucian "harmony" concept includes the natural harmony, the harmony between man and nature, the harmony between man and man and the harmony of the body and mind. Confucianism reaches its own harmony by moral cultivation, and then extended to the "harmony between man and man". "Ceremony", as the "harmony" is too precious to have, is embodiment of "harmony", and is the value goal of Confucianism and the perfect combination of "management means" and "management objectives".

The highest value and the ultimate goal of college students' work are to "realize students' freedom 
and all-round development" and "harmonious and stable" development environment is a prerequisite for its realization. "The time isn't as important as the terrain; but the terrain isn't as important as unity with the people.", as "harmony" is a perfect unity of "climate, geographical position and people's unity", and all aspects must achieve harmony to realize the comprehensive development of college students. Campus environment is the place for college students to study and live, which is the most closely related to the growth of students. The natural environment build in colleges and universities should try to reflect the humane factors, for example, the green belt construction and wall color design try to meet the students' behavior and habits, to cultivate students' "ownership", actively elaborates students' consciousness of subjective initiative and self-management, and from the details to cultivate students' quality of awareness.

The "harmony" advocated by Confucianism refers to "people's unity". The humanities environment of university involves all aspects of student study and life, including interpersonal relationship s school spirit and style of study and so on. Colleges and universities should strive to create good relationship in daily life between teachers and students, between students and students, let the teachers fully understand the students' thoughts 、opinions and intentions, so that student work can better serve the students. College and universities should build well atmosphere so as to form a good interpersonal relationship between the students, pay attention to enhance students' collective cohesion and friendship, and create a positive atmosphere for public opinion so as to improve the management efficiency.

\section{Conclusion}

Chinese traditional culture especially Confucianism influenced the Chinese for thousands of years. With the development of era, some content may not meet the needs of social development; however, the essence of Confucian culture to improve the humane quality of the university still plays a very active role. Confucian culture has become the core of Chinese traditional culture with its positive attitude and the spirit of opening to the outside world. The core of Confucianism is humanistic care. At present, the higher education is inclined to attach importance to improving the quality of science and technology, ignoring the cultivation of students the quality of humanities, so that colleges and universities should guide the students to learn the essence of Confucian culture, improve the humanistic quality of college students.

The Chinese traditional culture, which takes the Confucian culture as the core, attaches great importance to the efforts of the people and the cultivation of the moral spirit of the people. In the humanistic quality education of college students, we should pay attention to explore and carry forward the humanistic spirit of Confucianism, guide students to absorb the essence of Confucian humanism, and improve the humanistic quality of College students.

In short, Confucian "people-oriented", "benevolence", "harmony but different", "self-cultivate to appease others" and "harmony is most precious" are several aspects of the education management thought, have reference values for contemporary college student work.

In the era of advocating of "student oriented" and "quality education" today, to create "student oriented" work pattern has creative significance and is of great significance to promote humanities construction in students' all-round development.

\section{References}

1. Reisser, Linda. Education and Identity [M]. Jossey-Bass Publishers, 1993.

2. WangYang.A Study of Service-Learning in Ideological and Political Education of Colleges and Universities [D].Beijing Jiaotong University, 2012.

3. Rosenthal R, Jacobson L. Pygmalion in the classroom: teacher expectation and pupils' intellectual development [J]. Journal of Molecular Structure, 1969, 34(2):363-367.

4. Yang BoJun. The Analects of Confucius [M].Beijing: Zhonghua Book Company, 1958:288. 
5. Power C, Kohlberg L. Using a Hidden Curriculum for Moral Education [J]. Education Digest, 1987.

6. Angus J. MacNeil, Doris L. Prater, Steve Busch. The effects of school culture and climate on student achievement [J]. International Journal of Leadership in Education, 2009, 12(12):73-84.

7. Zhu S F. Film Appreciation and Fostering Higher Vocational College Students' Humanistic Quality [J]. Journal of Anhui Business College of Vocational Technology, 2011.

8. Zhao C M, Kuh G D. Adding Value: Learning Communities and Student Engagement [J]. Research in Higher Education, 2004, 45(2):115-138. 